\title{
The Importance of Social Media in Managing the Image of the Educational Institutions
}

\author{
Waldemar Jędrzejczyk ${ }^{1}$ and Stanisław Brzeziński²
}

ABSTRACT

\begin{abstract}
The subject of the article relates to the use of social media in organizational activities aimed at creating a positive image of an organization. The image is an important element of the organization's strategy - it shapes its distinctiveness, distinguishes it from competitors, and determines how the organization is perceived in the environment. Image is created at the interconnection between the organization and its stakeholders. A significant role in the process of shaping the image is played by marketing communication, which is subjected to increased virtualization due to the progressing digital transformation. The attributes of social media predestine them to be used in the process of image creation. The main purpose of this article is to assess the importance of social media in the process of managing the image of educational institutions. The rules of the market economy apply not only to business organizations but also increasingly to other types of organizations, including educational institutions. Following the example of enterprises, educational institutions must also build a positive image of the organization. In the presented empirical research results, the research subject was narrowed down to one type of educational institution, namely secondary schools. The research has shown that all analyzed schools use social media and the school's website as tools to promote and build their image in the local community. Unfortunately, the effectiveness of using these tools is low.
\end{abstract}

KEY WORDS: Image of the organization, social media, educational institutions, Poland.

JEL Classification: $\quad$ M10, M15, M31, M50.

Częstochowa University of Technology, Faculty of Management, Częstochowa, Poland

University of Economics and Human Sciences in Warsaw, Poland ${ }^{2}$

\section{Introduction}

The image of an organization is how the stakeholders perceive it-it is the depiction of the organization in the environment in which it operates (Alvesson, 1990; Chaturvedi \& Gupta, 2014; Frandsen, 2017; Negara et al., 2020). A positive image allows the organization to be distinguished amongst the competition, build the trust of recipients and gain their loyalty. The image may be deliberately and

Correspondence concerning this article should be addressed to: Waldemar Jędrzejczyk, Częstochowa University of Technology, Faculty of Management, Al. Armii Krajowej 19B 42-200 Częstochowa, Poland E-mail:waldemar.jedrzejczyk@wz.pcz.pl intentionally created by the organization. However, it is a complex process over which the organization has control only partially-it results from the essence of the image. The image management process should focus on two aspects:

1) Shaping own image, that is, the deliberate influence on the shape of the image from the stakeholders' point of view;

2) Collecting and analyzing the opinions of stakeholders in order to undertake corrective actions and to improve, strengthen and enforce the image.

The image concept should constitute an element 
of the overall marketing concept, strictly related to other components, and social media play an increasingly important role in contemporary marketing (Kaushik, 2012). Due to their attributes, social media are an optimal tool for use in the image creation process (Mangold \& Faulds, 2009). Numerous research proves that business organizations attach great importance to social media in conducting marketing activities, which aim at building the organization's image (MazurekŁopacińska \& Sobocińska, 2017)-this is an effect of progressing technological development and the growing potential of social media. The main benefits of present social media include (Kaplan \& Hanlein, 2010): wide range, general availability, low costs, mobility, interactivity and multimedia, higher level of effectiveness, and better engagement of the user. Social media allow existing in the virtual space, which is becoming as important as reality. It is often expressed that what is not in the media does not, in fact, exist. This notion indicates the need for regular and systematic research to diagnose what is happening in media reality. With this in mind, it is crucial to note that market economy principles apply not only to business organizations but also increasingly to other types of organizations, including educational institutions. Similarly to enterprises, educational institutions must also maintain good relations with their stakeholders (Kazoleas et al., 2001) and build a positive image of the organization (Alves \& Raposo, 2010; Ryńca \& Radomska, 2018).

The main purpose of this article is to assess the importance of social media in the process of managing the image of educational institutions. In the presented results of empirical studies, the analyzed entity was limited to one type of educational institutionsecondary schools.

The research did not cover the COVID-19 pandemic, which began in November 2019. Since the pandemic had a considerable impact on the functioning of schools, in particular on the organization and tenor of the educational process, this article poses a complementary problem question: does the period of the COVID-19 pandemic foster the use of IT tools and social media in the process of creating the image of educational institutions?

\section{The Process of Managing the Image of Educational Institutions}

The image, like any activity in the area of communication of an organization with the environment, should be carefully planned and supervised. Image management should be a continuous process as it requires conscious, systematic, and long-term actions (Massey, 2016). Managing the organization's image is not an easy task, mainly due to the substantial complexity of this phenomenon. To a large extent, the image is shaped regardless of the organization and does not always reflect reality. Thus, the process of managing the organization's image may be divided into the following stages (Schuler, 2004, Świeczak, 2017):

1. Defining the goals of building the desirable image of the organization;

2. Determining the main stakeholders of the organization;

3. Analyzing the present image of the organization;

4. Defining the determinants of the organization's image;

5. Selecting the instruments for creating the image and channels of communication with stakeholders;

6. Appointing the team and people responsible for executing image-related tasks;

7. Implementing and executing the image management strategy;

8. Supervising the achieved results.

The indicated stages in the process of managing the image of an organization enable to identify areas: 1) in the environment of the organization, where it is necessary to take action to create, strengthen or change the image of the organization; 2) within the organization itself, in which activities significantly affect the organization's image. These steps enable creating effective operational plans for building a positive image subjected to the mission and strategy of the organization. They make it easier to define the scope of activities for individual groups of employees and the degree of responsibility for contributing to building the organization's image.

As mentioned in the introduction, similarly to enterprises, educational institutions must also build a positive image of the organization. However, the specificity of creating the educational institutions' image is different than in the case of companies (Ryńca \& Radomska, 2018). It results from disparate management 
characteristics, different funding rules, and specific legal regulations. Managing the image of educational institutions, particularly secondary schools, is relatively easier than the analogical process carried out in business organizations. In the case of educational institutions, the following stages of the management process are comparatively simple (Jędrzejczyk, 2020a; Jędrzejczyk, 2020b):

1. It is easy to define the primary goal of schools' marketing activities - the main goal is to attract candidates during recruitment.

2 . It is easy to precisely determine the most important groups of stakeholders-the students. In the process of building a positive image of the organization, a proper definition of groups of stakeholders, particularly customers, plays a significant role.

3 . It is relatively easy to define the most crucial determinants of the image-in its ongoing marketing activity, the school should expose the most relevant elements for the student, such as educational offer, educational standards, the faculty, premises, and technical facilities.

4. It is relatively easy to select tools for image creation-the range of methods should include social media as the vast majority of youth in secondary schools use and is present in various social media outlets on a mass scale, where they create their own communities. Consequently, it is relatively easy to define the customer-student profile.

5. It is relatively easy to appoint people responsible for executing image-related tasks-in addition to schools principals, the teams should include all teachers since they are in direct contact with the most relevant schools stakeholders-the students.

There can be distinguished two basic models of building the organization's image: the linear model and the feedback model. The image building process, according to the linear model, consists of the following sub-processes: (a) The organization builds its identity based on its strengths; (b) Stakeholders receive and obtain information about the organization-about its weaknesses and strengths; (c) Based on the obtained information, stakeholders create the organization's image; image created by different groups of stakeholders may vary; (d) A combined image effect, defined as reputation, is developed; it consists of the sum of images created by individual groups of stakeholders, maintained over a longer period of time.

The linear model of building the organization's image is a non-closed system. It is a fundamental weakness of this model as information flow is conducted one-way only-from the organization to stakeholders.

In the feedback model of building the organization's image, in addition to sub-processes 1-4, there is also sub-process (e) the organization obtains information about its image, which may then be used in improvement activities. The feedback model is a closed model. The organization knows what are the effects of undertaken activities in the scope of building the image and, in case of a weak image, it can undertake corrective actions.

Due to the application of two-way communication in the feedback model, it seems natural to use social media in the process of shaping the relations of the organization with its environment.

\section{The Potential of Social Media}

Social media compose an extensive set of communication tools based on web applications and mobile technologies (Bingham \& Conner, 2010; Kaplan \& Haenlein, 2010). The most significant characteristics, which differentiate social media from traditional media include (Kaplan \& Hanlein, 2010; Gladwell \& Shirky, 2011; Heinonen, 2011; Laroche et al., 2012; Fill \& Turnbull, 2016):

1. Range-social media can reach a larger group of recipients;

2. Access-social media are generally accessible for many recipients free of charge or against a small price;

3. Use-creating content via social media does not require any special skills; it is enough to be able to use new technologies;

4. Immediacy-social media form a space where reactions are immediate;

5. Impermanence-messages may change almost the minute they were published;

6. Usability-social media are mainly based on what most users can do.

Social media include, among others: social networking sites (Facebook, Instagram, Tiktok, LinkedIn, Badoo), Wiki-type websites (Wikipedia), blogs (Blogger, WordPress, Photoblog), content sites (Pinterest, YouTube, Flickr, Slideshare, Vimeo), microb- 
logs (Twitter), online news sites (Wykop.pl, Reddit), forums (Gazeta.pl, Wizaz.pl, Kafeteria.pl), and messengers (WhatsApp, Skype, Facebook Messenger, Viber). Each type of social media features certain properties. They have radically changed the way people communicate (Bingham \& Conner, 2010). They turned communication into an interactive dialogue. This form of communication enables both the creation and exchange of user-generated content (Kaplan \& Haenlein, 2010). The use of social media by organizations increases customer involvement in the processes that take place in it (Kietzmann et al., 2011; Kaplan \& Haenlein, 2012; Barker et al., 2013; Mazurek-Łopacińska \& Sobocińska, 2017). More often, organizations treat social media as a marketing tool useful for image building, promoting and selling products, creating a potential customer base, conducting word-of-mouth marketing, and building a community around the organization.

\section{The Role of IT Tools and Social Media in Education During the COVID-19 Pandemic}

The COVID-19 pandemic poses a substantial problem in the modern world due to its negative effects on the global economy. Its fallout can be divided into three principal categories: (a) the burden imposed on the health systems and populations of affected countries; (b) the economic costs of measures adopted to limit the spread of the virus, and (c) the impact of the global economic slowdown on individual economies. The pandemic has rocked stock markets, shaken oil and other commodity markets, caused mass unemployment, increased extreme poverty, disrupted trade flows, led to food and medical shortages, and threatened the solvency of businesses and governments around the world. The pandemic has changed the functioning, to a greater or lesser extent, of almost all types of organizations. It also significantly affected the work organization of educational institutions as all types of schools were to switch from in-person to remote learning. In Poland, in-person classes were suspended for the first time on March 12, 2020. From March 25 to June 26, 2020, courses were held remotely. In subsequent school years 2020/2021 and 2021/2022, educational institutions implemented a hybrid system-in-person, hybrid, or online learning, depending on the number of reported cases of COVID-19 illnesses.
The functioning of educational institutions during a pandemic is regulated by legal acts developed by the Ministry of Education and Science. The new regulations on the organization of remote learning provide teachers with a wide range of possibilities to hold lessons using distance teaching methods and techniques, including electronic communication. According to the new regulations, schools are at liberty to choose the right teaching tool, taking into account all aspects related to the capacity of the school, the teachers, and above all, the technical and organizational capabilities of the students.

Implementing remote learning is a significant challenge for most teachers, for which they have not been previously prepared. Prior to the pandemic outbreak, $85,4 \%$ of the surveyed teachers had no previous experience with distance teaching (Centrum Cyfrowe, 2020) Holding online classes requires the use of new tools and different teaching methods. The most commonly used tools in remote learning are: communication apps, email, electronic grade books, educational platforms, group work tools using shared resources, and social media. These tools can be essentially categorized into: online classroom tools (Cisco Webex, Discord, Google Classroom, Google Meets, Live Streaming Facebook, Microsoft Teams, Skype, WhatsApp, Zoom), tools for establishing ongoing contact with students (E-grade book: Librus, Vulcan, etc., Messenger, Moodle, Skype), tools for uploading homework (E-grade book: Librus, Vulcan, etc., Google Classroom, Messenger, Microsoft Teams, Moodle, Watch2Gether, WhatsApp), assessment and testing tools (Kahoot, Socrative, Testportal, Quizizz, Quizlet), and tools for transferring the material in different forms (Canva, Eduelo, Genially, Google Maps, LearningApps, TVP Lessons, Jamboard, Mentimeter, Microsoft Excell, Microsoft PowerPoint, Microsoft OneNote, Microsoft Sway SketchNoting, ThingLink, Wordwall) (Buchner \& Wierzbicka, 2020).

Education is one of the social life areas most severely affected by the COVID-19 pandemic. Coronavirus has not only forced changes in the manner of communication, but it has also changed the way of consuming content on social media. With the pandemic and the resulting restrictions on social interaction, social media has become the main channel of communication for people. The rise in social media use, which was predicted even before the pandemic, has been confirmed 
in the numbers in the era of social distancing and quarantine. From the very first days of the lockdown, social media saw an increase in active users. Facebook saw a $50 \%$ increase in messaging across its platforms, including Messenger and WhatsApp. The exchange of private messages on Twitter increased by a third (IAB Polska, 2020) One of the latest reports from GlobalWebIndex indicates that the number of social media accounts per internet user has increased from 7,6 in 2017 to 8,1 in 2020 . The time spent on social media has also increased by a few minutes-now it is 2 hours and 22 minutes per day (Żyłowska, 2020).

Social media is already an inherent attribute of modern reality. Its role has become increasingly important when working remotely. For instance, social media allows schools to provide instant updates, rapid distribution, and immediate response from school stakeholders. Well-used social media can also significantly enrich the learning process by increasing the attractiveness of the learning content and the variety of teaching tools. The wide array of social media and its akin applications render these media useful in many areas of school activity. Most social media outlets capture much more traffic and user engagement than before. Naturally, it is a suitable time for schools to continue intensifying activities in social media, for ongoing communication between the school and its stakeholders, in order to create a positive image.

\section{The Importance of Social Media in Managing the Image of the Secondary Schools - Main Conclusions of Own Research}

\subsection{Research Method}

The main goal of the conducted empirical studies is to prepare a model approach to effective management of the image of educational institutions ${ }^{1}$. Three principal research questions are asked in relation to the main goal:

1. Is the potential of social media in the management of the image of educational institutions used effectively?

2. What are the main reasons for ineffective use of social media in managing the image of educational institutions?

3. How to manage the image of educational insti- tutions using social media, so that the process of creating the image was effective?

Responses to such questions were sought in a survey addressed to defined groups of respondents. The research was conducted in the years 2015-2019. In search for the answer to the research question in empirical studies, emphasis was put on those elements of the process of shaping the image, which depend on the organization and which should be combined with the use of social media. Three sub-processes were analyzed:

1. Building of organization's identity,

2. Communicating the organization's identity to stakeholders,

3. Obtaining feedback from stakeholders on the current image of the organization.

The main purpose of this article is to assess the importance of social media in the process of managing the image of educational institutions, which are divided into schools and educational establishments. The vast majority of educational institutions are schools, usually divided into primary, secondary, and higher education facilities. In publications regarding this field of study, it is relatively easy to find works regarding the issue of building the image of universities (e.g., Ivy, 2001; Alves \& Raposo, 2010; Suprapto \& Rosmala, 2012; Tess, 2013; Ryńca \& Radomska, 2018; Akıncı \& Serin, 2020), while it is significantly more difficult to find studies on the issue of building the image of secondary schools (e.g., Eger et al., 2018). This is because universities have been competing to acquire the best students for many years. However, the problem of increased competition on the educational services market has only started to apply to secondary schools recently. The main reason for this is the increasing demographic decline in many countries along with the simultaneous increase in the importance of school education as a social institution in the era of dynamic technological development. In Polish reality, the education reform introduced in 2017 is an additional factor.

Empirical research was conducted on two principal research populations. The first population comprised employees of secondary schools (principals, viceprincipals, and teachers), and the second one-main stakeholders-students and their parents. Schools were located in Poland in the Łódzkie voivodeship. 
201 employees participated in the research, including three principals, five vice-principals, and 193 teachers from thirteen secondary schools, as well as 1465 students from these schools and 467 parents of students. The research was conducted in 13 schools, where principals agreed to conduct this research. The research tool was auctorial survey questionnaires. The questionnaires developed for individual stakeholder groups differed slightly. Each questionnaire consisted of a core section and a metric. In the questionnaire for high school staff, the core section consisted of 29 questions. In the questionnaire for high school students, the core section consisted of 30 questions. In the questionnaire for parents of students, the core section consisted of 18 questions. The questions were of various types: open, semi-open, and closed-single choice and multiple choice; alternative questions and questions in the form of ranking scales. The survey was conducted once, and it was anonymous. The survey was in paper form, and it was distributed in an auditorium.

\subsection{Assessment of the Scale of Using Social Me- dia in the Process of Managing (Creating) the Image by Secondary Schools}

\subsubsection{Employee's perspective}

All analyzed secondary schools are already using social media, but the level of this use varies. All schools have accounts on at least one social media portal, and most-on at least two social media portals. The most popular social media service amongst secondary schools is Facebook-all schools use it. YouTube is also very popular. Other social media such as Messenger, Instagram, or Snapchat are used much less. It seems that schools still do not appreciate these applications, while they should. They have huge potential due to immense popularity amongst young people. In general, social media are seen as a good communication channel between the school and its stakeholders, in particular students and their parents ( $92 \%$ of respondents). The effectiveness of promotional activities carried out using social media is also deemed as high ( $87 \%$ of respondents).

\subsubsection{Main stakeholders' perspective}

The use of social media in the process of building the school's image is highly justified. At the moment, students have almost unlimited access to the Inter- net, which they mainly use in their natural environment-at home and in school. More or less, almost all students use social media-they have an account in at least one portal and use it daily (98\% of respondents). Within the scope of activity in social media, many students also share their opinions on Internet forums and blogs and comment on posted content (44\% of respondents).

Digital communication tools are also included in the portfolio of methods of promotion applied by schools. However, schools do not fully use the potential of applied methods, digital tools in particular. This is mostly visible in the case of social media. Less than half of respondents who receive information about the school via social media see this as an effective form of promotion.

\subsection{Reasons for the Low Efficiency of Using So- cial Media in the Process of Managing the Image of Secondary Schools}

\subsubsection{Employee's perspective}

The main reasons for the low efficiency of using social media in school activities include the absence of a social media strategy and the lack of systematic activities. These factors contribute to the remaining lowefficiency variables directly or indirectly: low level of use of social media in the promotion of individual education profiles, low substantive level of content published in social media, no incentives for stakeholders, small communities among the school's stakeholder groups, and the absence of employees responsible for the preparation and monitoring of content.

The school principals usually do not set clear directions for the use of social media in school promotional activities, do not monitor or analyze activities undertaken by school employees, do not appreciate teachers' activity and involvement in publishing valuable content, and do not analyze the opinions and comments posted by stakeholders in social media. The school should conduct activities in social media in an organized and systematic manner. However, respondents indicated that these activities are very often not organized or not systematic.

Respondents also indicated a lack of incentives for stakeholders, small school social media communities-groups of students, alumni, parents, employers 
who would create networks directly connected to the school, and a lack of staff responsible for preparing and monitoring content as reasons for the low efficiency of schools' use of social media in creating their image. In order for stakeholders to be active advocates of the school in social media, they should be systematically encouraged to do so. A similar remark also applies to school employees. There are no jobs for image specialists in schools. Therefore, there are no employees responsible for the preparation and monitoring of content published on social media by teachers and other stakeholders. The lack of incentives for stakeholders and employees contributes to a small school community in social media. The school's activities in social media lack permanent groups of parents, students, and graduates.

\subsubsection{Main stakeholders' perspective}

The specific reasons for the low efficiency of using social media in the process of managing the school's image were reflected in the identified expectations of the main school stakeholders-students and their parents, in terms of school activity in social media. Based on the analysis of the respondents' answers, eight main categories of expectations were distinguished. The respondents most often indicated that schools in social media channels should:

1. Operate in a planned and systematic manner.

2. Post latest news for students.

3. Post latest news for candidates.

4. Promote all education profiles.

5. Provide information and materials useful in the teaching process.

6. Draw attention to the attractiveness of the form of the presented content.

7. Encourage stakeholders to cooperate.

8. Take initiatives to increase community involvement in the school.

\subsection{Assessment of the Process of Creating an Image of Secondary Schools}

\subsubsection{Employee's perspective}

All school staff, including both the management and teachers, should be engaged in the process of shaping the school's image. Teachers play a crucial role as they have direct contact with students. From the teachers' perspective, things are looking good. In their opinion, they are engaging in the school's promotional activities, which aim at presenting and promoting information about the school's strengths (94\% of respondents). Many of them use social media to support these activities (68\%). Most engaged teachers undertake numerous activities in social media. They check information placed by the staff, students, and graduates, analyze opinions and comments, as well as post information, photographs, and films on daily life at the school.

Schools also attempt to obtain information about the quality of their work from main stakeholders. Unfortunately, these activities are not sufficient. Teachers indicated that opinions about the functioning of the school from students are usually obtained in direct discussions ( $85 \%$ of respondents). The greatest disadvantage of this manner of obtaining information is the questionable objectivity of received feedback due to the nature of the teacher-student relation.

Feedback from the second most important group of the school's stakeholders-parents of studentsis obtained mainly during parent-teacher meetings (92\%). The greatest disadvantage of this manner of obtaining feedback is significant inertia resulting from the low frequency of meetings, which usually take place four times a year.

On the other hand, opinions and comments posted by students and their parents on social media outlets are analyzed to a much lesser extent; this way of obtaining feedback was declared by $48 \%$ and $33 \%$ of the respondents respectively.

\subsubsection{Main stakeholders' perspective}

Opinions generated by current students and their parents significantly contribute to the school's image in the eyes of future students and their parents. Therefore, the process of monitoring these opinions, in particular in social media-where young people feel utterly no restrictions-is quite critical from the point of view of managing the school's image. Negative opinions should trigger corrective action.

\section{Discussion and Conclusions}

In the client's market era, the need to care for the image becomes a given. This concerns not only businesses but also public and social organizations, 
including educational institutions. Caring for the image and building it consciously is becoming a general practice in schools. The image also forms a significant element of the school's strategy, shapes its diversity, distinguishes it amongst the competition, and is decisive in terms of how the school functions and how it is perceived in the local community. The image is one of the most important factors that decide about choosing a particular school.

Image is created at the interconnection between the organization and its stakeholders. Marketing communication plays an important role in the process of shaping the image, as it becomes increasingly virtualized as a result of ongoing digital transformation. The new model of marketing communication is based primarily on social media.

In the process of shaping the school's image, many schools still concentrate mainly on building their identity and communicating it to their stakeholders and, to a much smaller degree, on obtaining and analyzing feedback. Therefore, in theory, the image is built in a closed system-the feedback model, and, in practice, in an open system-the linear model. The linear model uses classical public relations tools based on one-way communication such as the press, television, radio, and door open days. The effects of such activities, however, are characterized by substantial inertia. These restrictions are not present in the case of social media.

In the process of image management, schools do use social media, but the results of studies demonstrate that activities in this area are insufficient. All analyzed schools use social media and the school's website as tools to promote and build their image in the local community, which is undoubtedly a strength. However, the low effectiveness of using these tools is the weak point. The current scale of using social media in schools may be surprising, taking into account the nature of this tool. For the first time in history, organizations may use tools with huge potential, for which they do not have to pay, and which offer unlimited access as the only condition is access to the Internet. They may also be certain that this tool is used by stakeholders, especially when the main stakeholders are young people.

\section{Recommendations}

Conclusions from the research may contribute to the development of a collection of recommendations, which may help schools increase the effectiveness of using social media in the process of managing their image. A collection should contain the following recommendations:

1. Activities of schools in social media should be systematic and inscribed in the school development strategy.

2. The strategy should ultimately contribute to goals and operational plans, which should precisely define what information should be published, by whom, at what time, and in which media.

3 . The school should use a wide variety of social media in its activities as well as the functionality of individual media as much as possible.

4. All school employees should be involved in the school's activities on social media. However, it is necessary to appoint people responsible for monitoring the content published in social media about the school, and these activities should be additionally remunerated.

5. Schools should present initiatives taken in social media among the employees. Appreciation of the mostinvolved employees by the school management will certainly be a factor motivating other teachers to actively participate in activities in this area.

\section{Limitations}

The considerations presented in the article do not exhaust the issues and require further research. The limitation of the study is the sampling method and its sizethe research was conducted in one country, in one type of school, and on a relatively small research population. A larger sample would provide a better generalization of the results.

\section{Footnotes}

${ }^{1}$ Research is conducted by a research team managed by Waldemar Jędrzejczyk, the co-author of this article. The principal study area concerns the issue of competences, both those currently desirable as well as prospective, referring to sectors, kinds and types of organizations, professional groups, and key positions in organizations. In the area of the organization's competences to create the image using social media, the main owner is Marta Konieczna-Kucharska. 


\section{References}

Akıncı, H.B., \& Serin, H. (2020). The relationship between organizational image and organizational citizenship perception of academicians. International Journal of Education and Literacy Studies, 8(1), 1423. https://eric.ed.gov/?id=EJ1246196

Alves, H., \& Raposo, M. (2010). The influence of university image on student behavior. International Journal of Educational Management, 24(1), 81-82. https:// doi.org/10.1108/09513541011013060

Alvesson, M. (1990). Organization: From substance to image? Organizational Studies, 11(3), 373-394. https://doi.org/10.1177/017084069001100303

Barker, M., Barker, D., Bormann, N., \& Neher, K. (2013). Social media marketing: A strategic approach. Cengage Learning..

Bingham, T., \& Conner, M. (2010). The new social learning: A guide to transforming organizations through social media. Berrett-Koehler Publishers.

Buchner, A., \& Wierzbicka, M. (2020). Edukacja zdalna w czasie pandemii. Raport z badań. Edycja II. https://centrumcyfrowe.pl/wp-content/uploads/ sites/16/2020/11/Raport_Edukacja-zdalna-w-czasie-pandemii.-Edycja-II.pdf

Chaturvedi, S., \& Gupta, S. (2014). Social media - a new tool in modern era marketing. International Journal of Engineering Sciences \& Management Research, 1(2), 80-86.

Centrum Cyfrowe. (2020) Edukacja zdalna w czasie pandemii. Raport $z$ badań [Distance education during the pandemic. Research report. 2nd Edition]. https://centrumcyfrowe.pl/wp-content/uploads/ sites/16/2020/05/Edukacja_zdalna_w_czasie_pandemii.pptx-2.pdf

Eger, L., Egerová, D., \& Pisoňová, M. (2018). Assessment of school image. CEPS Journal, 8(2), 97-122. https:// doi.org/10.26529/cepsj.546

Fill, C., \& Turnbull, S. (2016). Marketing communications: Discovery, creation and conversations. Pearson.

Frandsen, S. (2017). Organizational image. In C. Scott, \& L. Lewis (Eds.), The international encyclopedia of organizational communication, 4 Volume Set (pp. 1795-1804). John Wiley \& Sons. https://doi. org/10.1002/9781118955567.wbieoc103

Gladwell, M., \& Shirky, C. (2011). From innovation to revolution. Do social media make protests possible? Foreign Affairs, 90(2), 153-154.

Heinonen, K. (2011). Consumer activity in social media: Managerial approaches to consumers' social media behavior. Journal of Consumer Behavior, 10, 356364. https://doi.org/10.1002/cb.376
Ivy, J. (2001). Higher education institution image: A correspondence analysis approach. International Journal of Educational Management, 15(6), 276282. https://doi.org/10.1108/09513540110401484

Jędrzejczyk, W. (2020a). Managing the image of an educational institution in the social media era. In K. S. Soliman (Ed.), Education excellence and innovation management: A 2025 vision to sustain economic development during global challenges (pp. 8563-8573). International Business Information Management Association (IBIMA).

Jędrzejczyk, W. (2020b). Use of social nedia in open and closed models of building the educational institutions' image. In K. S. Soliman (Ed.) .), Education excellence and innovation management: A $2025 \mathrm{vi}$ sion to sustain economic development during global challenges (pp. 9051-9060). International Business Information Management Association (IBIMA).

Kaplan, A. M., \& Haenlein, M. (2012). Social media: Back to the roots and back to the future. Journal of Systems and Information Technology, 14(2), 101104. https://doi.org/10.1108/13287261211232126

Kaplan, A. M., \& Haenlein, M., (2010). Users of the world, unite! The challenges and opportunities of social media. Business Horizons, 53(1), 59-68. https://doi.org/10.1016/j.bushor.2009.09.003

Kaushik, R. (2012). Impact of social media on marketing. International Journal of Computational Engineering \& Management, 15(2), 91-95.

Kazoleas, D., Kim, Y., \& Moffitt, M. (2001), Institutional image: A case study. Corporate Communication an International Journal, 6(4), 205-216. https://doi. org/10.1108/EUM0000000006148

Kietzmann, J. H., Hermkens, K., McCarthy, I. P., \& Silvestre, B.S. (2011). Social media? Get serious! Understanding the functional building blocks of social media. Business Horizons, 54(3), 241-251. https://doi.org/10.1016/j.bushor.2011.01.005

Laroche, M., Habibi, M. R., Richard, M. O., \& Sankaranarayanan, R. (2012). The effects of social media based brand communities on brand community markers, value creation practices, brand trust and brand loyalty. Computers in Human Behavior, 28(5), 17551767. https://doi.org/10.1016/j.chb.2012.04.016

Mangold, G. W., \& Faulds, D. J. (2009). Social media: The new hybrid element of the promotion mix. Business Horizons, 52, 357-365. https://doi.org/10.1016/j. bushor.2009.03.002

Massey, J. E. (2016). A theory of organizational image management. International Journal of Management and Applied Science, 2(1), 1-6.

Mazurek-Łopacińska, K., \& Sobocińska, M. (2017). 
Media społecznościowe $\mathrm{w}$ procesach komunikacji przedsiębiorstwa $\mathrm{z}$ rynkiem [Social media in the processes of business-market communication]. Marketing i Zarzadzanie, 1(47), 343-352.

Negara, D. J., Mantikei, B., Meitiana, Christa, U. R., \& Sintani, L. (2020). Psychological effect of brand image and brand reputation on sustainable firm performance in Indonesian logistics. Contemporary Economics, 14(4), 428-443. https://doi.org/10.5709/ ce.1897-9254.416

Ryńca, R., \& Radomska, J. (2018). Modelling the strategy of university image management. Przeglad Organizacji, 5, 13-20. https://doi.org/10.33141/ po.2018.05.02

Schuler, M. (2004). Management of the organizational image: A method for organizational image configuration. Corporate Reputation Review, 7(1), 37-53. https://doi.org/10.1057/palgrave.crr.1540210

IAB Polska. (2020). Social media w czasie zarazy [Social media during the pandemic]. http://covid.iab.org. pl/wp-content/uploads/2020/04/Social-Media-wczasachzarazy_20.04.2020.pdf

Suprapto, F., \& Rosmala, D. (2012). Study of social networking usage in higher education environment. Procedia - Social and Behavioral Sciences, ELSEVIER, 67, 156-166. https://doi.org/10.1016/j.sbspro.2012.11.316

Świeczak, W. (2017). Wizerunek instytucji badawczej jako istotny element $\mathrm{w}$ kształtowaniu poziomu konkurencyjności organizacji [The image of the scientific institution as an important factor in shaping the level of competitiveness of the organization]. Marketing Instytucji Naukowych i Badawczych, 2(24), 81-104. 10.14611/minib.24.06.2017.03

Tess, P.A. (2013). The role of social media in higher education classes (Real and virtual) - A literature review. Computers in Human Behavior, ELSEVIER, 29(5), A60-A68. https://doi.org/10.1016/j.chb.2012.12.032

Żyłowska, K. (2020, 4 August). Jak pandemia zmieniła nasze podejście do mediów społecznościowych [How the pandemic changed our approach to social media]? https://socialpress.pl/2020/08/jakpandemia-zmienila-nasze-podejscie-do-mediowspolecznosciowych 